\title{
Editorial
}

\section{Do We Now Have a 'Couch Potato' Blood Test?}

\author{
Ernesto Crisafullia ${ }^{a}$ David M. Mannino ${ }^{b}$ \\ ${ }^{a}$ Department of Medical and Surgical Sciences, University of Modena and Reggio Emilia, Modena, Italy; \\ ${ }^{b}$ Department of Preventive Medicine and Environmental Health, University of Kentucky College of \\ Public Health, Lexington, Ky., USA
}

In recent years the role of polymorbidity in chronic diseases has become the focus of increased research. This is particularly true among patients with chronic obstructive pulmonary disease (COPD), where the development of underlying and frequently unrecognized cardiac disease may dramatically change the prognosis of patients [1].

A hallmark of COPD, cardiovascular disease, and other chronic diseases is both a decreased capacity for physical activity (PA) (i.e. what a patient can do) along with decreased levels of activity (i.e. what a patient actually does). PA is any bodily movement (e.g. daily walking) produced by skeletal muscles that results in energy expenditure [2]. The American College of Sports Medicine and the American Heart Association recommend for all adults aged 18-65 years moderate-intensity aerobic PA for at least $30 \mathrm{~min}$ daily at least 5 days a week [3]. COPD patients in stable condition are frequently sedentary, even if they have the capacity for higher levels of activity [4]. Moreover, in this patient population daily PA is an important predictor of mortality and hospitalization [5].

A challenge clinicians face is the inability to rapidly and objectively assess PA in their patients with chronic disease. Some cardiac biomarkers, however, show some promise in this regard. In response to increased cardiac stress, atrial natriuretic peptide (ANP) and adrenomedul- lin (ADM) are released from myocardial cells in the atria and from adrenal medulla, respectively. The midregional pro-molecular forms of ANP (MR-proANP) and ADM (MR-proADM), which remain in the circulation longer than mature molecules, have been suggested as biomarkers with prognostic value in COPD exacerbations $[6,7]$.

Data from the PROMISE (Predicting Effects and Risk Factors in Exacerbations of Chronic Obstructive Pulmonary Disease) study by Jehn et al. [8] is published in this issue of Respiration. Their results show among moderateto-severe stable COPD patients a significant inverse correlation between the daily walking activity (measured by accelerometers) and the level of MR-proANP and MRproADM. Stated differently, lower levels of time spent walking ( $\mathrm{min} /$ day or number of steps/day) predict higher levels of these cardiac-related biomarkers. These results provide a plausible means of 'connecting the dots' between COPD severity, inactivity, and cardiac disease with this measure of cardiac stress (levels of MR-proANP and MR-proADM) [6, 7] and PA [5].

This study highlights the need for objective and easily obtained measures of the daily level of activity in the comprehensive assessment of COPD patients to identify the patients at increased risk for exacerbation and mortality. Expanding criteria in the classification of COPD severity beyond lung function [5] to include cardiac

\section{KARGER}

Fax +4161306 1234

E-Mail karger@karger.ch

www.karger.com (c) 2012 S. Karger AG, Basel

0025-7931/13/0853-0193\$38.00/0

Accessible online at:

www.karger.com/res
Ernesto Crisafulli, MD, $\mathrm{PhD}$

Department of Medical and Surgical Sciences

University of Modena and Reggio Emilia

Via del Pozzo 141, IT-41100 Modena (Italy)

E-Mail ecrisafulli@ pneumonet.it 
measures will give a better picture of our patient's current level of functioning and prognosis [9]. The addition of a simple blood test that provides information as to the PA of the patient (i.e. is this person, regardless of their capacity, reasonably active or a 'couch potato'?) is intriguing.
With interest we await future studies aimed at evaluating whether any interventions (e.g. pulmonary rehabilitation) modify the level of cardiac distress circulating biomarkers. In addition, this measure may be important as a biomarker useful in evaluating new pharmacological approaches to the treatment of COPD and its comorbid diseases.

\section{References}

$>1$ Macchia A, Rodriguez Moncalvo JJ, Kleinert M, Comignani PD, Gimeno G, et al: Unrecognised ventricular dysfunction in COPD. Eur Respir J 2012;39:51-58.

$\checkmark 2$ Caspersen CJ, Powell KE, Christenson GM: Physical activity, exercise, and physical fitness: definitions and distinctions for healthrelated research. Public Health Rep 1985; 100:126-131.

3 Haskell WL, Lee IM, Pate RR, Powell KE, Blair SN, Franklin BA, et al: American College of Sports Medicine, American Heart Association: Physical activity and public health: updated recommendation for adults from the American College of Sports Medicine and the American Heart Association. Circulation 2007;116:1081-1093.
4 Pitta F, Troosters T, Spruit MA, Probst VS, Decramer M, Gosselink R: Characteristics of physical activities in daily life in chronic obstructive pulmonary disease. Am J Respir Crit Care Med 2005;171:972-977.

5 Garcia-Rio F, Rojo B, Casitas R, Lores V, Madero R, Romero D, et al: Prognostic value of the objective measurement of daily physical activity in patients with COPD. Chest 2012;142:338-346.

6 Bernasconi M, Tamm M, Bingisser R, Miedinger D, Leuppi J, Muller B, et al: Midregional proatrial natriuretic peptide predicts survival in exacerbations of COPD. Chest 2011;140:91-99.
Stolz D, Christ-Crain M, Morgenthaler NG, Miedinger D, Leuppi J, Mueller C, et al: Plasma proadrenomedullin but not plasma proendothelin predicts survival in exacerbations of COPD. Chest 2008;134:263-272.

8 Jehn M, Schindler C, Meyer A, Tamm M, Koehler F, Witt C, et al: Associations of daily walking activity with biomarkers related to cardiac distress in patients with COPD. Respiration 2013;85:195-202.

9 McGarvey LP, John M, Anderson JA, Zvarich M, Wise RA, TORCH Clinical Endpoint Committee: Ascertainment of cause-specific mortality in COPD: operations of the TORCH Clinical Endpoint Committee. Thorax 2007;62:411-415. 